\title{
Oral lipoma of unusual size and location: a case report
}

\author{
- Paula Verona Ragusa Silva Discipline of Clinical Stomatology, Department of Stomatology, School of Dentistry, University \\ of São Paulo, São Paulo, SP, Brazil • Suzana Cantanhede Orsini Machado de Sousa Discipline of Oral Pathology, Department \\ of Stomatology, School of Dentistry, University of São Paulo, São Paulo, SP, Brazil • Fábio Abreu Alves Discipline of Clinical \\ Stomatology, Department of Stomatology, School of Dentistry, University of São Paulo, São Paulo, SP, Brazil
}

\begin{abstract}
A lipoma is a slow-growth benign tumor of the adipocytes. In the oral cavity, it is more commonly observed in the buccal mucosa; other sites less affected are the tongue, floor of the mouth, and lips. The objective of this report is to describe an extensive tumor affecting the dorsum of the tongue and the therapeutic maneuver performed. A 63-yearold man was referred to our clinic for evaluation of a tumor in the dorsum of the tongue with 6 months of duration. The physical examination revealed an extensive nodule, asymptomatic, submucosal, in the dorsum of the tongue at the left that measured approximately $4 \mathrm{~cm}$. On palpation, the lesion was mobile and had rubbery consistency. According to these findings, the diagnostic hypotheses were lipoma and neurofibroma. Hence, surgical excision was performed and during the procedure a yellowish and well-delimited lesion was observed. The surgical specimen floated in $10 \%$ formalin. The histopathological examination confirmed the diagnosis of lipoma. The patient is asymptomatic after 40 months of follow-up. This report describes an unusual presentation of lipoma on the dorsum of the tongue and demonstrates that this lesion can reach large proportions.
\end{abstract}

DESCRIPTORS | Lipoma; Tongue Diseases; Mouth Neoplasms; Tongue Neoplasms.

RESUMO | Resumo Lipoma oral de tamanho e localização incomuns: relato de caso • Lipoma é um tumor benigno de crescimento lento dos adipócitos. Na cavidade oral, é mais comumente observado na mucosa jugal; outros sítios menos afetados são a língua, soalho oral e lábios. O objetivo deste relato é descrever um extenso tumor afetando o dorso da língua e a manobra terapêutica realizada. Um homem de 63 anos de idade foi encaminhado à nossa clínica para avaliação de um tumor no dorso da língua com 6 meses de duração. O exame físico revelou um nódulo extenso, assintomático, submucoso, no dorso da língua à esquerda, medindo aproximadamente 4 cm. À palpação, a lesão era móvel e tinha consistência borrachoide. De acordo com esses achados, as hipóteses diagnósticas foram lipoma e neurofibroma. Portanto, foi realizada excisão cirúrgica e, durante o procedimento, foi observada uma lesão amarelada e bem delimitada. O espécime cirúrgico flutuou em formalina a 10\%. O exame histopatológico confirmou o diagnóstico de lipoma. O paciente encontra-se assintomático após 40 meses de acompanhamento. Este relato descreve uma apresentação incomum de lipoma no dorso da língua e demonstra que essa lesão pode atingir grandes proporções.

DESCRITORES | Lipoma; Doenças da Língua; Neoplasias Bucais; Neoplasias da Língua.

CORRESPONDING AUTHOR
- Fábio Abreu Alves Discipline of Clinical Stomatology, Department of Stomatology, School of Dentistry, University of São Paulo • Av. Professor Lineu Prestes, 2227 São Paulo, SP, Brazil • 05508-000 E-mail: faalves@usp.br

- Received Mar 4, 2015 - Accepted Apr 16, 2015

- Dol http://dx.doi.org/10.11606/issn.2357-8041.clrd.2016.106226 


\section{INTRODUCTION}

Lipoma is a benign tumor of mature adipocytes that presents a slow-growing and is usually asymptomatic. The tumor's consistency may vary from rubbery to flaccid, according to fibrous tissue amount. ${ }^{1,2}$ It usually has intact surface, but ulceration can occur in case of secondary trauma. ${ }^{3}$ Although being considered the most common mesenchymal neoplasm, this tumor is relatively uncommon on the mouth and the main sites affected are buccal mucosa, tongue, floor of the mouth, and lips. ${ }^{4}$

Regarding the size, the tumor may vary from few centimeters to large proportions ${ }^{5}$ and the latter can cause significant alteration in the organ function, such as difficulty to speak, chew, and swallow. ${ }^{6}$ The aim of this study is to report an extensive lipoma involving the dorsum of the tongue. In addition, its clinical implications and treatment are also emphasized.

\section{CASE REPORT}

A 63-year-old man was referred to the Stomatology Department due to an extensive enlargement on the dorsum of the tongue with 6 months of duration: the medical history showed controlled diabetes; the intraoral examination revealed a well-delimited asymptomatic nodule, located on the dorsum of the tongue, measuring around $4.0 \mathrm{~cm}$, and covered by normal $\mathrm{mu}-$ cosa (Figure $1 \mathrm{~A}$ and $1 \mathrm{~B}$ ); on palpation, the lesion was mobile and rubbery. According to these findings, we raised the diagnostic hypotheses of lipoma and neurofibroma. A surgical excision was proposed and during the procedure a wellcircumscribed yellowish lesion with a smooth surface was totally removed (Figure 2 and 3). The lesion floated in formalin solution (Figure 4). The histopathological examination exhibited a large number of mature adipocytes interspersed with bands of connective tissue. It also presented some small caliber congested blood vessels
(Figures 5 and 6). Hence, the diagnosis of lipoma was confirmed. The patient is asymptomatic for 40 months (Figure 7).

\section{DISCUSSION}

Lipomas are mesenchymal neoplasms that are uncommon in the oral cavity. Usually, oral lipomas manifest as asymptomatic, slow-growing, and submucosal nodules.7 They occur mainly in the buccal mucosa, followed by tongue, floor of the mouth, and lips. ${ }^{3}$ However, considering the tongue neoplasms, lipomas account for only $0.3 \%$ of them. ${ }^{8}$ A recent review about tongue lipomas showed that most of the cases had less than $2.0 \mathrm{~cm}$ of diameter (average of $2.1 \mathrm{~cm}$ ), and the largest tumor had 6.0 x 6.0 x $5.0 \mathrm{~cm}$. Furthermore, the lateral region of the tongue was the main site affected. ${ }^{9}$ In general, it has soft to rubbery consistency and floates. ${ }^{5}$ However, an atypical form of lipoma called infiltrative lipoma can invade muscle tissue and recur after excision. ${ }^{10}$ A Brazilian study evaluating 41 oral lipomas showed a predominance of women (ratio 2.4:1) and a peak incidence in the sixth and seventh decades. ${ }^{11}$ However, another study performed in the Brazilian population ${ }^{12}$ did not find gender predilection. Recently, it was proposed that diabetes is associated with the incidence of oral lipoma, as well as trauma, chronic stimulation and heredity. ${ }^{2}$ Disruption of adipocyte maturation process can be caused by mutations in mitochondrial DNA, and diabetic patients are exposed to such mutations. ${ }^{13}$ Our patient reported to have controlled diabetes.

Although microscopical lipoma can be classified into several subtypes, the histopathological aspect of the lesion is characteristic. A classic lipoma usually has a circumscribed and non-encapsulated aggregate of mature adipocytes, with an abundant and clear cytoplasm and absence of cellular atypia and metaplasia. ${ }^{14}$ This description is consistent with the histopathological findings of our study. 
The treatment of choice is surgical resection, 9 since the tumor is easily excised and usually do not recur. However, for infiltrative lipomas, the recommendation is the removal with healthy tissue margin to prevent recurrence. ${ }^{1,12}$ The delay in the treatment of major tongue lipomas can lead to difficulty in speech, breathing, and swallowing, as well as atrophy of the lingual muscles and dental alterations. ${ }^{15}$ The treatment in this case consisted of surgical excision and the patient is asymptomatic after 40 months.

\section{CONCLUSION}

This report describes an unusual presentation of lipoma due to its clinical dimension and location. Therefore, it is important to include lipoma in the differential diagnosis of extensive lesions involving the tongue.
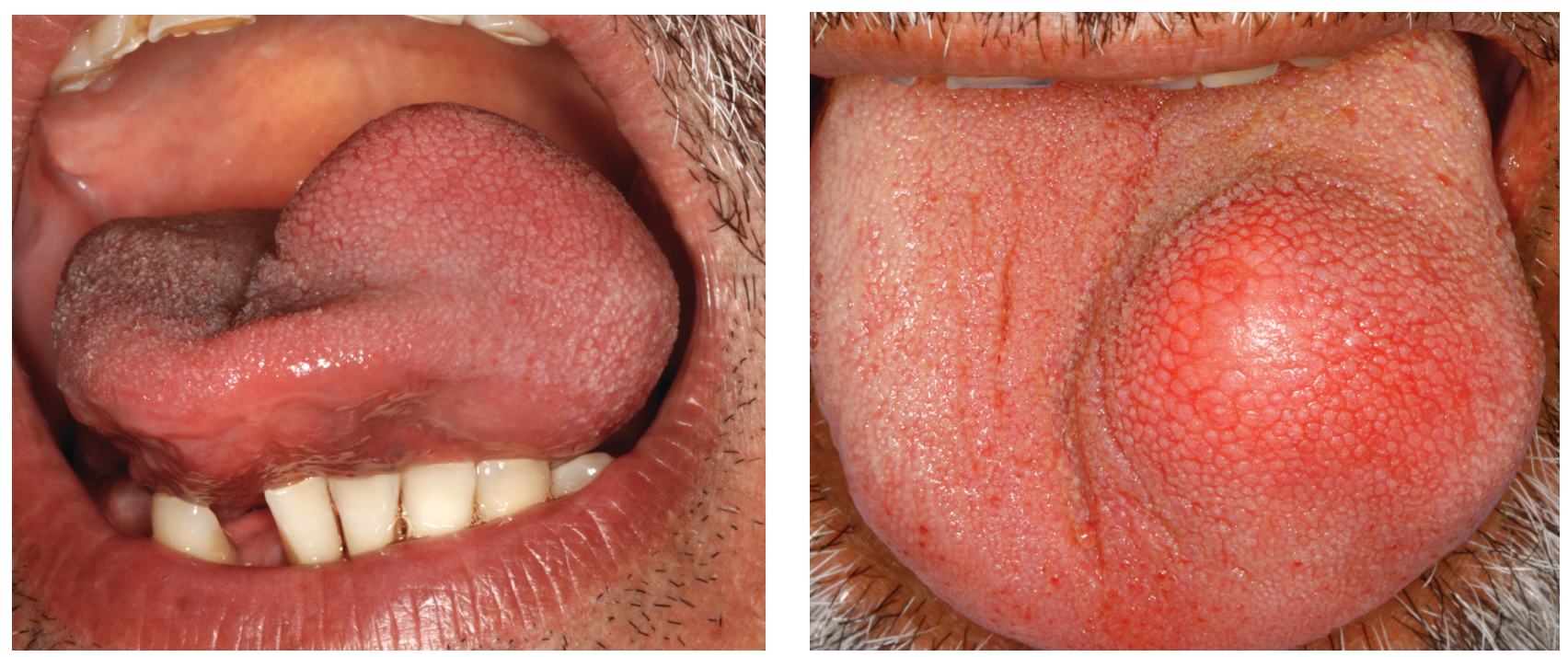

Figure 1A and 1B | Extensive swelling on the dorsum of the tongue with intact surface.

On palpation, the lesion was mobile with rubbery consistency.

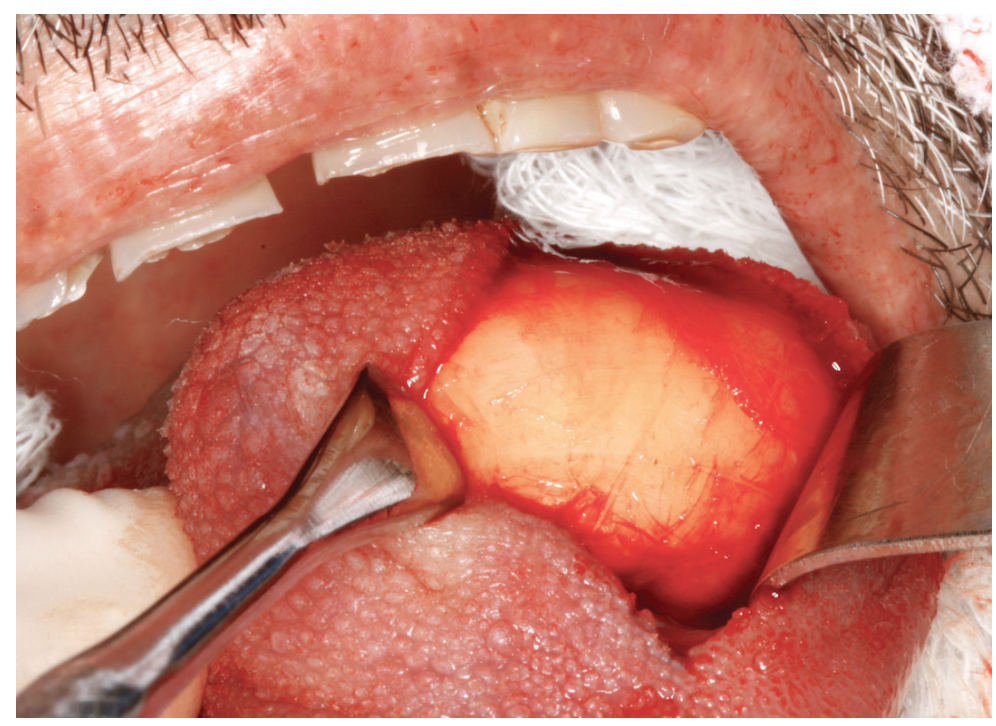

Figure 2 | Trans-surgical showing a yellowish and well-delimited lesion not adhered to the deep plans. 


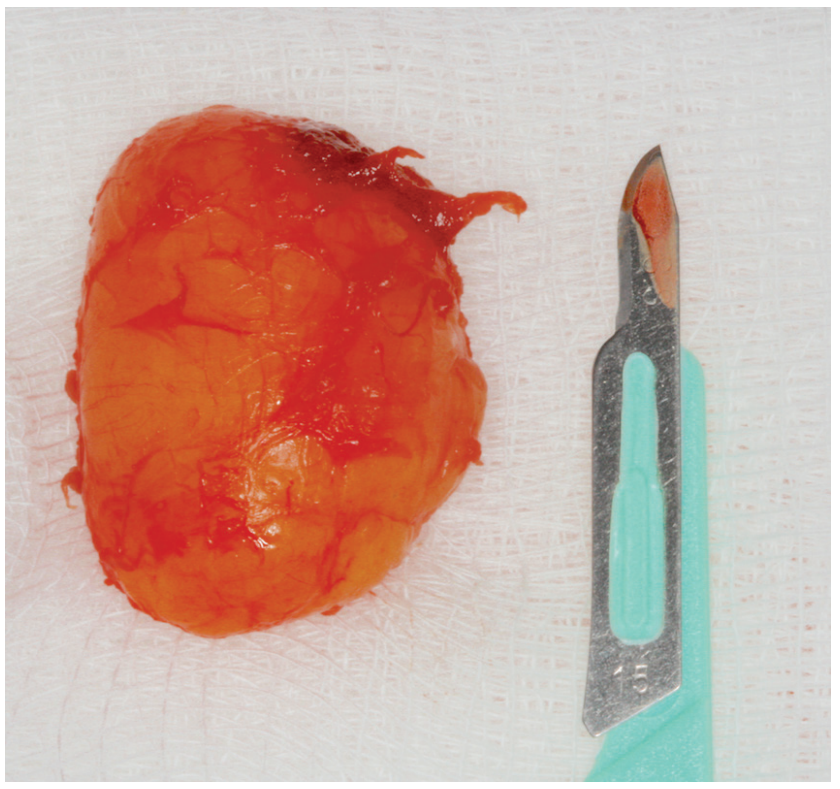

Figure 3 | Specimen measuring $3.7 \mathrm{~cm} \times 2.4 \mathrm{~cm} \times 1.8 \mathrm{~cm}$.

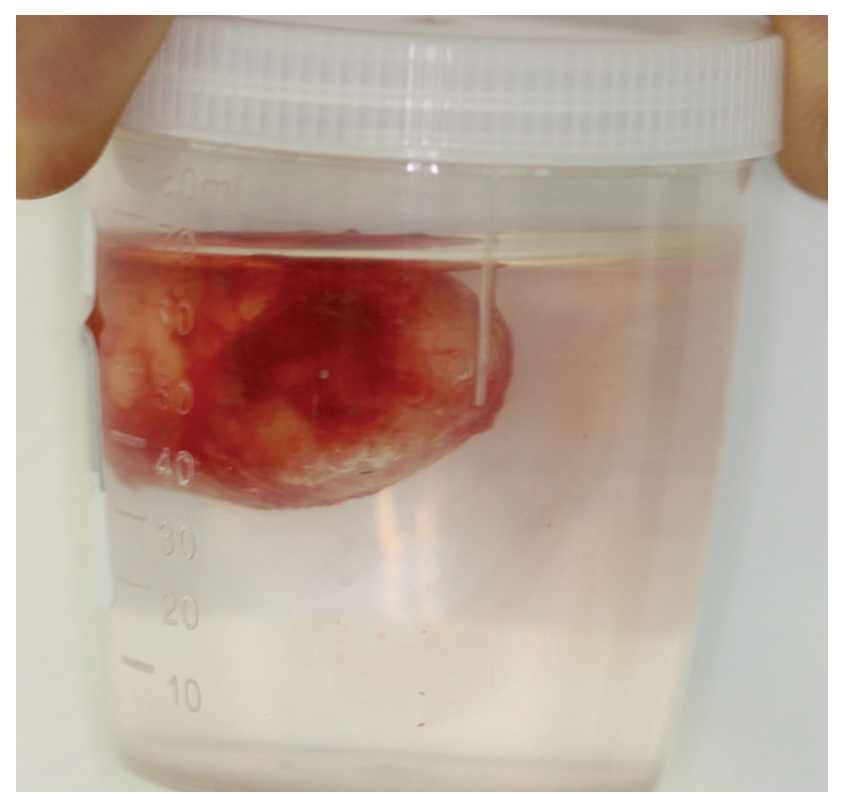

Figure 4 | Specimen floating in formalin solution.

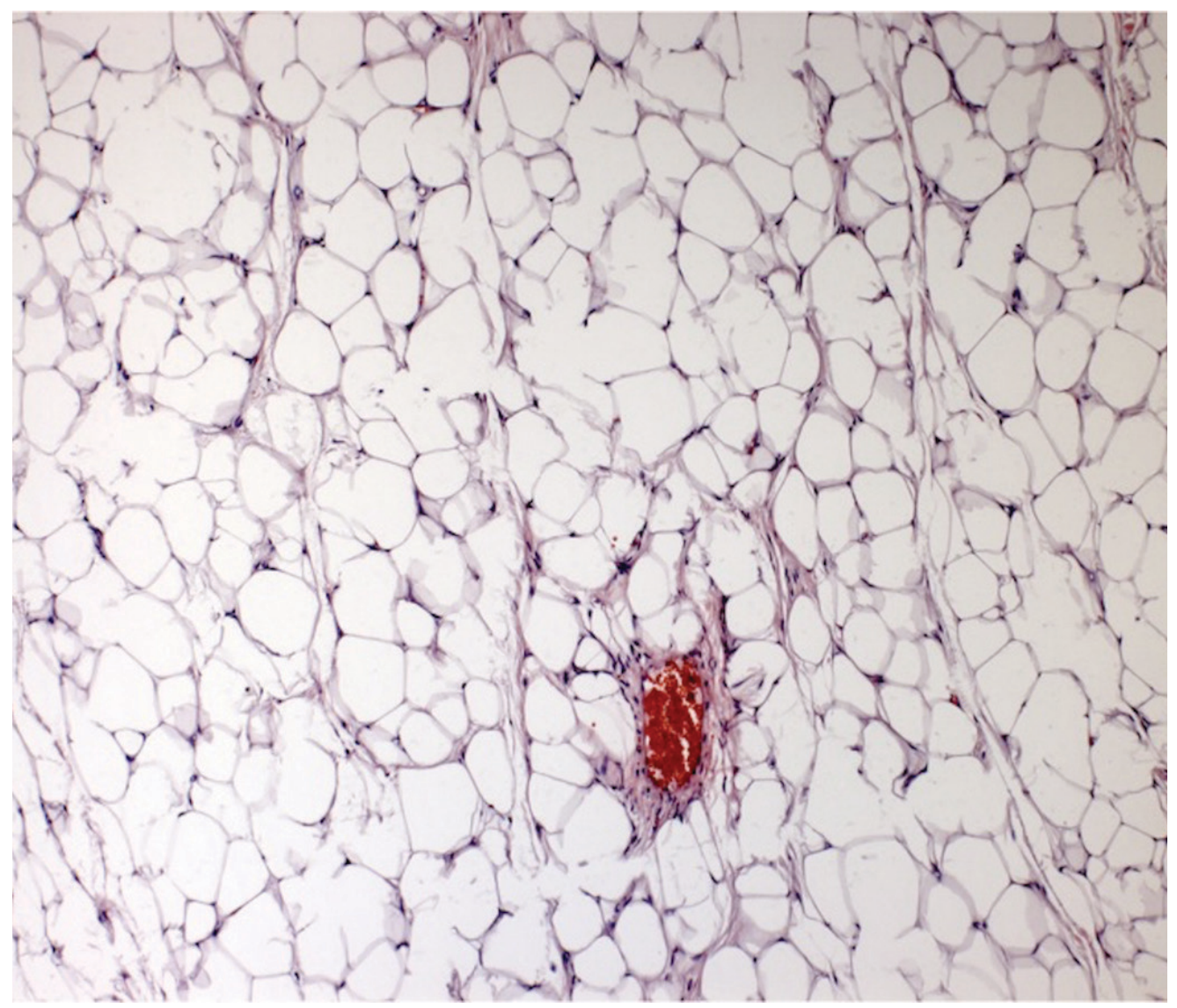

Figure 5 || Mesenchymal neoplasm fragment exhibiting large number of mature fat cells, some congested blood vessels of small caliber, and some muscle fiber bundles. 


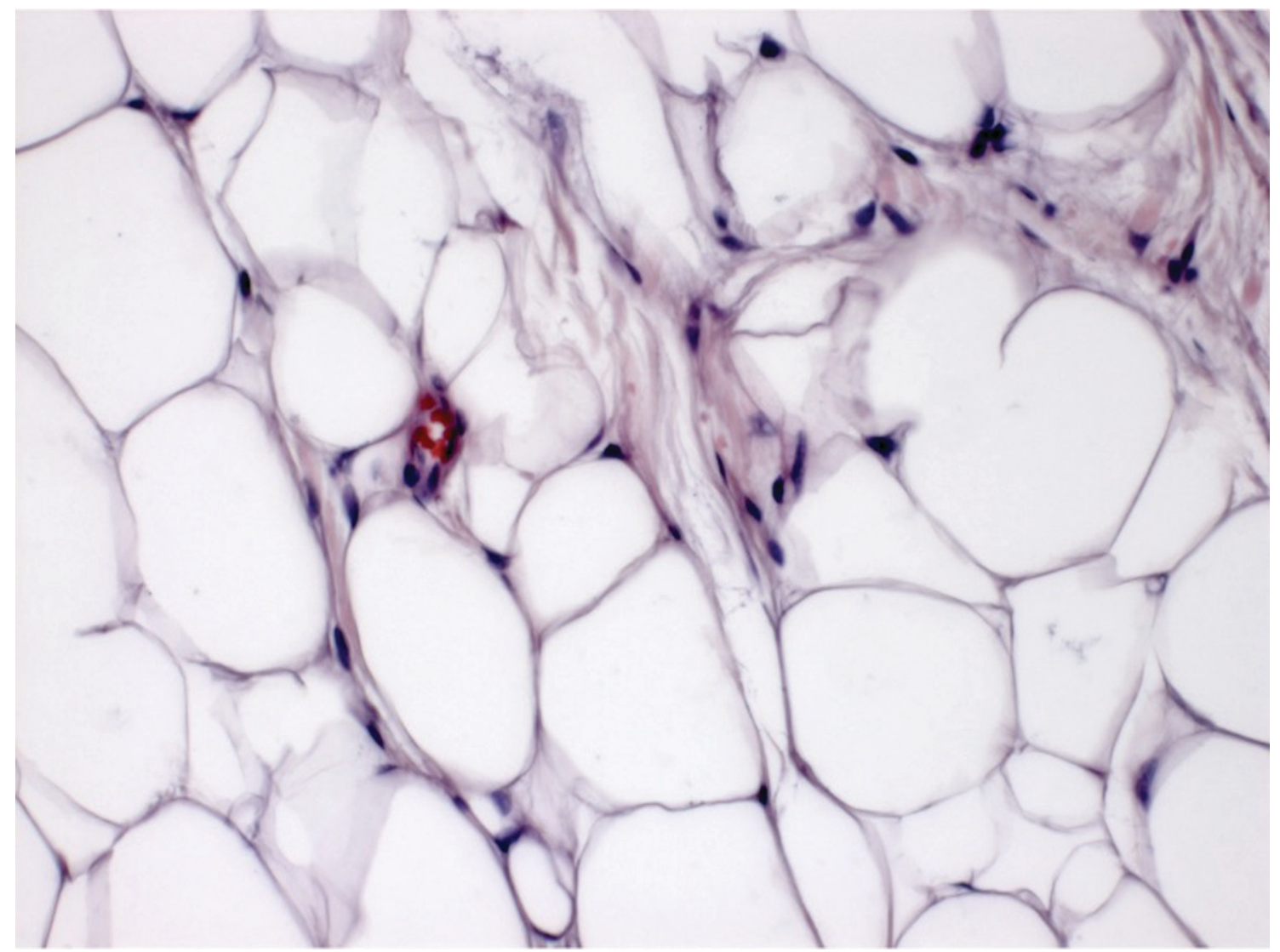

Figure 6 | Mature fat cells, arranged in a lobular arrangement, interspersed with bands of connective tissue.

Figure 7 | Complete healing and no signs of recurrence. Patient is asymptomatic after 40 months of follow-up.

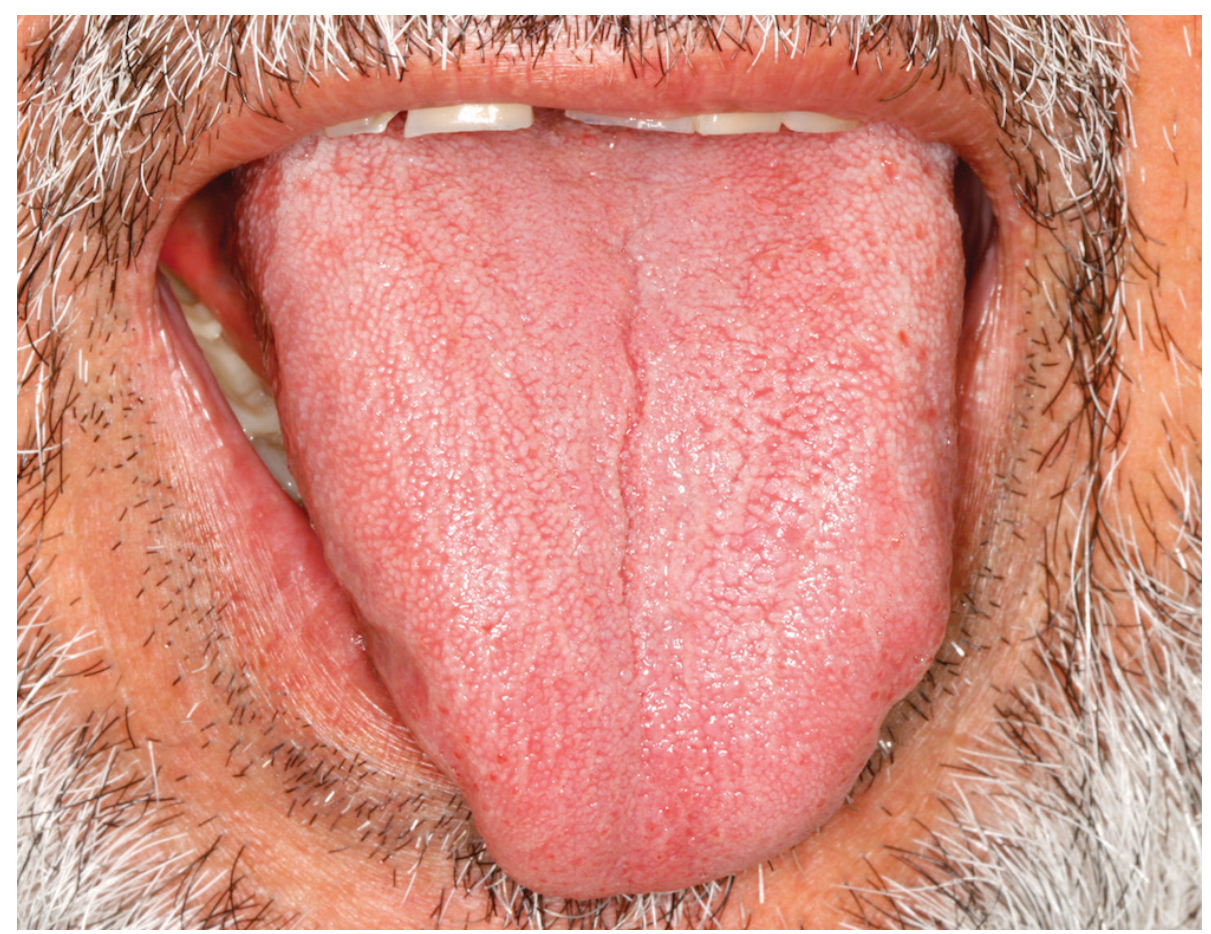




\section{REFERENCES}

1. Chandak S, Pandilwar PK, Chandak T, Mundhada R. Huge lipoma of tongue. Contemp Clin Dent. 2012 Oct-Dec;3(4):507-9. doi: 10.4103/0976-237X.107457.

2. Park BG, Choi DJ, Park JW, Kim JS. Oral cavity lipoma: a case report. J Korean Assoc Oral Maxillofac Surg. 2015 Aug;41(4):213-6. doi: 10.5125/jkaoms.2015.41.4.213.

3. Venkateswarlu M, Geetha P, Srikanth M. A rare case of intraoral lipoma in a six year-old child: a case report. Int J Oral Sci. 2011 Jan;3(1):43-6. doi: 10.4248/IJOS110o8.

4. Lee SH, Yoon HJ. Bilateral asymmetric tongue classic lipomas. Oral Surg Oral Med Oral Pathol Oral Radiol. 2012 Jul;114(1):e15-8. doi: 10.1016/j.tripleo.2011.07.045.

5. Agarwal R, Kumar V, Kaushal A, Singh RK. Intraoral lipoma: a rare clinical entity. BMJ Case Rep. 2013 Jan;2013. doi: 10.1136/bcr-2012-007889.

6. Raj AA, Shetty PM, Yadav SK. Lipoma of the floor of the mouth: report of an unusually large lesion. J Maxillofac Oral Surg. 2014 Sept;13(3):328-31. doi: 10.1007/s12663-011-0204-2.

7. Bandeca MC, de Padua JM, Nadalin MR, Ozorio JE, Silva-Sousa YT, da Cruz Perez DE. Oral soft tissue lipomas: a case series. J Can Dent Assoc. 2007 Jun;73(5):431-4.

8. Damghani MA, Safari M. Huge tongue lipoma: a case report. Iran J Otorhinolaryngol. 2015 Mar;27(79):165-9.

9. Lu SL, Zheng JJ, Wu H, Li T, Dong G, Wang YL, et al. Tongue lipoma in an older male: a case report and literature review of patients with tongue lipoma reported in China. Oncol Lett. 2016 Jan;11(1):419-22. doi: 10.3892/ol.2015.3865.

10. Sekar B, Augustine D, Murali S. Lipoma, a rare intraoral tumor: a case report with review of literature. Oral Maxillofac Pathol J. 2011 Jul-Dec;2(2):174-7.

11. Juliasse LE, Nonaka CF, Pinto LP, Freitas RA, Miguel MC. Lipomas of the oral cavity: clinical and histopathologic study of 41 cases in a Brazilian population. Eur Arch Otorhinolaryngol. 2010 Mar;267(3):459-65. doi: 10.1007/soo405009-1010-z.

12. Fregnani ER, Pires FR, Falzoni R, Lopes MA, Vargas PA. Lipomas of the oral cavity: clinical findings, histological classification and proliferative activity of 46 cases. Int J Oral Maxillofac Surg. 2003 Feb;32(1):49-53. doi: http://dx.doi. org/10.1054/ijom.2002.0317.

13. Holme E, Larsson N, Oldfors A, Tulinius M, Sahlin P, Stenman G. Multiple symmetric lipomas with high levels of mtDNA with the tRNA (Lys) A--> G(8344) mutation as the only manifestation of disease in a carrier of myoclonus epilepsy and ragged-red fibers (MERRF) syndrome. Am J Hum Genet. 1993 Mar;52(3):551-6.

14. Adoga AA, Nimkur TL, Manasseh AN, Echejoh GO. Buccal soft tissue lipoma in an adult Nigerian: a case report and literature review. J Med Case Rep. 2008 Dec;2(1):382. doi: 10.1186/1752-1947-2-382.

15. Magadum D, Sanadi A, Agrawal JM, Agrawal MS. Classic tongue lipoma: a common tumour at a rare site. BMJ Case Rep. 2013 Jan;2013. doi: 10.1136/bcr-2012-007987. 